Human Biogeography 
This page intentionally left blank 


\title{
Human Biogeography
}

\author{
Alexander H. Harcourt
}

甲

UNIVERSITY OF CALIFORNIA PRESS

Berkeley · Los Angeles · London 
University of California Press, one of the most distinguished university presses in the United States, enriches lives around the world by advancing scholarship in the humanities, social sciences, and natural sciences. Its activities are supported by the UC Press Foundation and by philanthropic contributions from individuals and institutions. For more information, visit www.ucpress.edu.

University of California Press

Berkeley and Los Angeles, California

University of California Press, Ltd.

London, England

(C) 2012 by the Regents of the University of California

Library of Congress Cataloging-in-Publication Data

Harcourt, A. H. (Alexander H.)

Human biogeography / Alexander H. Harcourt. p. $\mathrm{cm}$.

Includes bibliographical references and index.

ISBN 978-0-520-272I I-8 (cloth : alk. paper)

I. Human geography. 2. Physical anthropology.

3. Biogeography. I. Title.

$\mathrm{GF}_{4} \mathrm{I} . \mathrm{H}_{375} 2 \mathrm{OI} 2$

$304.2-\mathrm{dc} 23$

2011052055

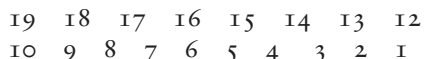

The paper used in this publication meets the minimum requirements of ANSI/NISO Z39.48-I992 (R I997)

(Permanence of Paper).@

Cover image: Detail from map of native languages and language families from Handbook of North American Indians, Vol. 17, Languages, ed. Ives Goddard.

Smithsonian Institution (GPO), I996. 